\title{
The in vivo toxicity evaluation of leaf and root methanolic extracts of Tephrosia vogelii Hook.f using animal model
}

\author{
Stephano Hanolo Mlozi ${ }^{1,2^{*}}$, Juma A. Mmongoyo ${ }^{2}$ and Musa Chacha ${ }^{1}$
}

\begin{abstract}
Background: Traditionally, herbal medicines are commonly used to cure several diseases since immemorial of human life. Nevertheless, the safety of some traditionally used medicinal plants is uncertain. Since Tephrosia vogelii Hook.f is a traditionally used medicinal plant, the effects of its extracts were evaluated on lethality $\left(L D_{50}\right)$ and subacute toxicity in this study.

Methods: Phytochemistry screening and an in vivo toxicity evaluation of leaf and root methanolic extracts of $T$. vogelii using laboratory albino rats were conducted. Methanolic extracts of doses 600, 1200, 2000 and $5000 \mathrm{mg} / \mathrm{kg}$ body weights were administered single dose in rats to observe deaths within $72 \mathrm{~h}$ in order to determine the $L_{50}$. Methanolic extracts doses of 600, 1200 and $2000 \mathrm{mg} / \mathrm{kg}$ body weights were consecutively administered for 14 days in order to evaluate sub-acute toxicity.

Results: Tannins, steroids, terpenoids, flavonoids and saponins were identified in the phytochemical screening. The $\mathrm{LD}_{50}$ experiments revealed zero deaths of rats for the administered doses, 600 to $5000 \mathrm{mg} / \mathrm{kg}$ body weight. Histopathological examination of liver and kidney for sub-acute toxicity test showed safety at all doses except root methanolic extracts dose of $2000 \mathrm{mg} / \mathrm{kg}$ which exhibited necrosis and vacuolation of liver cells on the 14th day. Nonetheless, hepatic necrosis and hepatic vacuolation disappeared upon time elongation without dose administration to 28th day.
\end{abstract}

Conclusion: The conducted toxicity evaluation of methanolic leaf and root extracts in albino rats revealed no deleterious effects, henceforth, suggesting that $T$. vogelii could be safe to users using it as a medicinal plant.

Keywords: Herbal medicines, Tephrosia vogelii Hook.f, Methanolic extracts, Lethality, Sub-acute toxicity

\section{Introduction}

Traditionally, humans have used herbal medicines for remedying various diseases since immemorial times. Uses of medicinal plants as herbal medicines have been increasing worldwide due to the philosophy of low cost, effectiveness, availability and fewer side effects compared to synthetic petrochemical-derived drugs $[1,2]$. This philosophy coincides with the fact

\footnotetext{
* Correspondence: hanolos@nm-aist.ac.tz

${ }^{1}$ School of Life Science and Bioengineering, Nelson Mandela African Institution of Science and Technology, P.O. Box 447, Arusha, Tanzania

${ }^{2}$ Department of Chemistry, University of Dar es Salaam, Mkwawa University College of Education, P.O. Box 2513, Iringa, Tanzania
}

that medicinal plants have played a great role in drug discovery and contributed more than $25 \%$ of the available pharmaceuticals [2, 3] Principally, the potentiality of medicinal plants can be attributed to their ability to synthesize voluminous metabolites such as flavonoids, stilbenoids, alkaloids, steroids, quinones, glycosides, and terpenoids. These secondary metabolites have demonstrated significant bioactivities against diseases inflicting humans, animals, and plants $[3,4]$. Notably, the ethnopharmacological reports have shown that the chemical functionalities and bioactivities of the metabolites from the herbal plants vary due to geographical factors. For example,

\section{Springer Open}

() The Author(s). 2020 Open Access This article is licensed under a Creative Commons Attribution 4.0 International License, which permits use, sharing, adaptation, distribution and reproduction in any medium or format, as long as you give appropriate credit to the original author(s) and the source, provide a link to the Creative Commons licence, and indicate if changes were made. The images or other third party material in this article are included in the article's Creative Commons licence, unless indicated otherwise in a credit line to the material. If material is not included in the article's Creative Commons licence and your intended use is not permitted by statutory regulation or exceeds the permitted use, you will need to obtain permission directly from the copyright holder. To view a copy of this licence, visit http://creativecommons.org/licenses/by/4.0/. 
there is evidence that harsh tropical climate influences herbal plants to synthesize more metabolites to counter to the stimuli than in less-harsh climatic conditions $[1,2]$ They synthesize secondary metabolites in order to either to respond against the stress caused by the harsh conditions or generate defensive chemicals against the predators supported by conditions on the given geographic orientations $[1,3]$. Thus, such plants become potential herbal plants of varying abilities to produce herbal medicines to treat diseases.

Nevertheless, some studies have questioned the bioactivities of traditionally used medicinal plants because of their side effects they cause once administered to humans and animals $[5,6]$. This questioning is valid because the toxicity effects of secondary metabolites from herbal medicines may be lethal or non-lethal. There is enough evidence that shows that herbal medicines can have negative effects on animals and humans [3, 7-9]. Thus, the common belief that those concoctions from medicinal plants are natural and generally regarded as safe (grass) does not always hold true. Therefore, evaluating the toxicities of herbal bioactivities is necessary particularly when the bioactives are amenable to the development of drugs for treating human ailments.

Tephrosia vogelii Hook.f. is a medicinal plant used ethnomedically for the treatment of skin infection diseases, scabs, deworming and ectoparasites [10-16]. It has also been used traditionally in fishing activities and as traditional pesticides in local agricultural activities for many decades [17-19]. The pharmacological study of methanolic extracts of $T$. vogelii revealed its antimicrobial activities [16, 20]. The pharmacological studies on bioactive compounds such as rotenoids and steroids from $T$. vogelii revealed the potentiality of such compounds for development of pesticides and insecticide [11-19]. Although more bioactive compounds are potential antimicrobial agents that could lead to the development of drugs for treating human ailments, the leaves of $T$. vogelii have been reported to contain bioactive compounds, tephrosin and rotenone, which had exhibited toxicity in fishes [15-18]. Unfortunately, little or no attention has been paid to the extensive toxicity evaluation of herbal bioactives from this medicinal plant despite its toxicity in fish. The toxicity evaluation is crucial because many people, particularly the poor, depend on the plant for treatment of human ailments and local prevention of pests in farms. Scientific study for toxicity assessment particularly on vital organs such liver and kidney which highly involved with excretion and detoxification are overemphasized to establish safeties of this used medicinal plants. Thus, this study aims to evaluate the toxicity of methanolic leaf and root extracts of $T$. vogelii so as to establish a toxicity profile.

\section{Materials and methods}

\section{Plant materials and extraction}

The leaves and roots of Tephrosia vogelii were collected from Hai district, Moshi region; Northern part in Tanzania (Latitude S $03^{\circ} 15^{\prime} 6.4^{\prime \prime}$ and longitude E $37^{\circ}$ $\left.14^{\prime} 3.8^{\prime \prime}\right)$. The plant species was identified by the plant taxonomist and botanist, Mr. E. John from Tanzania Pesticides Research Institute (TPRI), and the voucher specimen (SH-NM102) was deposited at the Nelson Mandela African Institution of Science and Technology for future reference. The plant materials were air-dried under the shade for 4 weeks then pulverized to powder. The pulverized leaves $(0.6 \mathrm{~kg})$ and roots $(0.45 \mathrm{~kg})$ were separately soaked in methanol for $48 \mathrm{~h}$ followed by filtration to obtain methanolic filtrates. Methanol solvent was completely evaporated using a rotary evaporator under low pressure below $40^{\circ} \mathrm{C}$. The evaporation afforded 12.0 $\mathrm{g}$ and $5.0 \mathrm{~g}$ of methanolic leaf extracts (TV-L, ME) and methanolic root extracts (TV-R, ME), respectively. Then the extracts were stored at $4{ }^{\circ} \mathrm{C}$ prior to biological assays.

\section{Phytochemical screening}

Phytochemical screening of secondary metabolites was conducted according to standard procedures as previously described [21-24].

\section{Test for tannins}

The distilled water $(1 \mathrm{~mL})$ was added to $0.5 \mathrm{~g}$ of extract. Then the mixture was stirred, filtered and few drops of ferric chloride were added to the filtrate. The formation of blue-black precipitates indicated the presence of tannins.

\section{Test for terpenes and steroids}

About $0.1 \mathrm{~g}$ of the extract was dissolved in $1 \mathrm{~mL}$ of chloroform. Then $1 \mathrm{~mL}$ of acetic anhydride was added to the mixture. Finally, two drops of concentrated sulfuric acid were added gently to the mixture alongside the test tube. Changes of colour from violet to blue/green indicate the presence of steroids while changes from violet to pink-red indicated the presence of terpenoids.

\section{Test for saponins}

About $0.5 \mathrm{~g}$ of extract was added to $5 \mathrm{~mL}$ of distilled water and shaken well. Then the mixture was gently warmed. Persistent frothing even after warming indicated the presence of saponins. 


\section{Test for flavonoids}

About $15 \mathrm{~mL}$ of distilled water was added to about 0.25 $\mathrm{g}$ of plant extracts, and then mixture was filtered. The filtrate, about $10 \mathrm{~mL}$ were collected which then divided into two test tubes each containing $5 \mathrm{~mL}$. Then $5 \mathrm{~mL}$ of $20 \%$ sodium hydroxide was added to $5 \mathrm{~mL}$ of the filtrate. In another tube of $5 \mathrm{~mL}$ of the filtrate $5 \mathrm{~mL}$ of lead acetic solution was added. Formations of yellow colour with either of the reagents added to the filtrate confirmed the presence of flavonoids.

\section{Test for alkaloids}

About $0.5 \mathrm{~g}$ of the extract was added to $3 \mathrm{~mL}$ of $1 \%$ aqueous hydrochloric acid and stirred in a steam bath. The mixture was then filtered, and $1 \mathrm{~mL}$ of the filtrate was poured into two test tubes, each containing $0.5 \mathrm{~mL}$. Finally, 3 drops of Mayer's reagent were added to one of the test tubes, and 3 drops of $1 \%$ picric acid were added to another test tube. The formation of precipitates with any of the final added two reagents confirmed the presence of alkaloids.

\section{Test for glycosides}

About $0.1 \mathrm{~g}$ of extract was dissolved in $1 \mathrm{~mL}$ of glacial acetic acid containing one drop of ferric chloride solution. Then $1 \mathrm{~mL}$ of concentrated sulphuric acid was added to the mixture by pouring alongside the test tube. The brown ring formation indicated the presence of glycosides.

\section{Experimental animals and doses}

Animal model experiments were performed in accordance with OECD guidelines 423 and 407 for toxicity assessment $[25,26]$ and the previous methods with minor modifications [27-32]. Fifty-five laboratory albino rats aged 8 weeks were collected from Sokoine University of Agriculture (SUA). All rats were housed in plastic cages and treatments. Acclimatization was for 7 days. They were fed food three times a day; in the morning, afternoon and evening to make sure that they did not starve and die. For easy administration of drugs to rats through oral gavage, water was not provided in the morning to induce thirst. Thus, water was given in the afternoon immediately after the administration of the drugs and during the evening. Extracts doses of $600,1200,2000$ and $5000 \mathrm{mg} / \mathrm{kg}$ body weight were employed $[27,33]$. The body weights of the animals were measured using analytical balance before the drug administration regime in order to prepare appropriate doses. Weights of animals were $150 \pm 5 \mathrm{~g}$ of which the doses were calculated on the average weight of $150 \mathrm{~g}$. The amount of extracts used to prepare concentrations (doses) was established based on the calculation of the "ratio of expected dose multiplied by the weight of rats". Then, 90, 180, 300 and $750 \mathrm{mg}$ of methanolic leaf and root extracts of $T$. vogelii were measured regarding rats weights and expected doses. Extracts were dissolved in $1 \mathrm{~mL}$ of distilled water to obtain $90,180,300$ and $750 \mathrm{mg} / \mathrm{mL}$ solutions, which were equivalent to doses 600,1200 , 2000 and $5000 \mathrm{mg} / \mathrm{kg}$, respectively, for dosage in rats.

\section{Animal welfare and safety}

The Tanzania animal welfare Act [34] as well as other ethical guidelines for the consideration of animal rights such as the use of few numbers of animals, treatment with or without minimal pain and age of animals, were observed during experimental research $[35,36]$. In this study, all rats were safely caged with the intention of protection (rats neither suffocated nor died because of unconducive environments). The sacrificed bodies and organs were sterilized and incinerated after the experiments.

\section{Lethal dose $\left(L D_{50}\right)$ assay: groups of animals and treatment}

Twenty-seven rats were grouped into nine groups; each group consisted of three rats based to minor modification from previous studies [27, 37]. Animal groups were housed in separate plastic cages for ease observation and treatments. The $\mathrm{LD}_{50}$ test was an in vivo experiment whereby a single dose of the extract(s) administered to laboratory albino rats so as to evaluate doses causing deaths. Both root and leaf methanolic extracts of $T$. vogelii of doses $600,1200,2000$, and $5000 \mathrm{mg} / \mathrm{kg}$ were administered to rats to determine the $\mathrm{LD}_{50}$ extracts within $72 \mathrm{~h}$. Except for the control group (group 9) which was not treated with extracts, the same dose was administered to all three animals of each group. The leaf methanolic extracts (TV-L, ME) of doses 600, 1200, 2000 and $5000 \mathrm{mg} / \mathrm{kg}$ were administered to four groups of rats (groups 1, 2, 3 and 4), respectively. The root methanolic extracts (TV-R, ME) of doses 600, 1200, 2000 and $5000 \mathrm{mg} / \mathrm{kg}$ were administered to four groups of rats (groups 5, 6, 7 and 8), respectively. The lethality was conducted followed by sub-acute toxicity assay.

\section{Sub-acute toxicity assay: groups of animals and treatment} The sub-acute toxicity assay was performed through an animal model using laboratory albino rats at SUA. Twenty-eight albino rats were divided into seven experimental groups, and each group had four rats. Each group was housed in an independent plastic cage for conducting treatments. Animal doses were modified from previous studies from Upadhyay and colleagues [38]. The TV-R, ME doses of 600, 1200 and $2000 \mathrm{mg} / \mathrm{kg}$ were used to treat groups 1,2 , and 3 , respectively. The TV-L, ME doses of 600, 1200 and $2000 \mathrm{mg} / \mathrm{kg}$ were used 
to treat groups 4, 5, and 6, respectively. Group 7 was not treated with extracts as it served as a control group. The dosage regime of the animals with extracts was consecutively conducted once per day for 14 days. The dose administrations were done at noon and made through oral gavaging followed by clinical signs observations. Toxicity (clinical) signs were recorded at the interval of $10 \mathrm{~min}, 0.5 \mathrm{~h}, 1 \mathrm{~h}, 4 \mathrm{~h}, 8 \mathrm{~h}$ and $24 \mathrm{~h}$ immediately after oral dose administration. The clinical signs of toxicity such as water intake, mortality, food intake, sedation, convulsion and general behaviour to the treated animals were recorded for 28 days. In each group, two animals were anaesthetized and sacrificed at the day 15th and two animals at the day 29th. Sacrificed animals were conducted in order to see the effects of prolonged administered extracts in 14 days (day 1-14) and when animals stopped receiving doses from day 15-28. Animals were anaesthetized by ketamine/xylazine, 20:1 $\mathrm{mg} / \mathrm{kg}$ intraperitoneal $(20: 1 \mathrm{mg} / \mathrm{kg}$ IP) injection to avoid pain during dissection. After the anaesthesia reached depth, the animals were sacrificed then kidney and liver organs were removed for histopathological examination. These organs were preferred because they are the target organs involved in the detoxification and excretions of the ingested harmful substances, which are more likely to manifest negative effects in the cells of the organs [6]. The drug effects particularly negative manifestation were studied and collected as histopathological data.

\section{Histopathology}

The liver and kidney were collected from the sacrificed and dissected rats then washed with $10 \%$ neutral buffered formalin (NBF) solution. The macroscopic examination was carried out using normal eyes before fixation and staining for microscopic examination. The organs were trimmed and processed for paraffin embedding. Then fixation was carried out whereby about $4 \mu \mathrm{m}$ thick sections of the embedded were prepared and stained with hematoxylin $(\mathrm{H})$ and eosin $(\mathrm{E})$. The stained tissues in slides were then analyzed with the aid of an optical microscope to observe, if any, signs of cell degenerative changes such as inflammation and necrosis evidence. The optical microscopic analyses captured the images with the microscope Motic B1 series and scanned the images through micro-camera Moticam 480 using the Motic Images Plus 2.0 Mult-Language Application Suite Software. The histopathological analyses of hepatic-renal toxicity effects in animals' organs treated with extracts were established and compared with the control organs of the untreated animals.

\section{Results and discussion}

Medicinal plants are good candidates for the health care system as herbal medicines against diseases perpetrating human beings and animals' husbandry. Concurrently, their worth sources are attested beyond doubts in recent years whereby many researchers have paid more attention to the exploitation of the herbal medicines for the development of antimicrobial products [37-39]. However, little is done to carry out toxicity evaluation of such herbal medicines. The toxicity evaluation of herbal medicines is necessary because evidence has shown that some herbal bioactive agents have negative effects contributed with secondary metabolites [3, 6-8, 40-43] Our study aimed to determine toxicity of root and leaf methanolic extracts of $T$. vogelii regarding the reported ethnopharmacological potentiality. Explicitly, the lethality $\left(\mathrm{LD}_{50}\right)$ and sub-acute toxicity of methanolic leaf and root extracts of $T$. vogelii were evaluated using the animal model. The results intended to establish a toxicity profile that would serve as a guide and/or precaution to usage of $T$. vogelii as the medicinal plant for curing various human diseases. The clinical signs are presented in Tables 1 and 2 while the histopathological examinations are presented in Figs. 1, 2, and 3. On the other hand, the phytochemical screening was carried out to determine the nature of secondary metabolites present in the methanolic root and leaf extracts. The identified metabolites were tannins, steroids, terpenes, flavonoids and glycosides (Table 3).

As for $\mathrm{LD}_{50}$ assessment; the methanolic root and leaf extracts of $T$. vogelii administered at the doses of $600,1200,2000$, and $5000 \mathrm{mg} / \mathrm{kg}$ did not exhibit any mortality in the rats within $72 \mathrm{~h}$. However, sedation was observed as a clinical toxicity manifestation for the animals administered with both root extracts and leaf extracts at $5000 \mathrm{mg} / \mathrm{kg}$ body weight (Table 1). The root and leaf extract dose at $5000 \mathrm{mg} / \mathrm{kg}$ caused a sedative sign for two out of three treated rats, and the experiential signs witnessed just half an hour after administration. The clinical sign disappeared with 2 hours. The sedation suggested the presence of toxicants in the extracts such as rotenoids which are commonly responsible for the bioactivities reported in the same plant species [44-46]. The rotenoids especially rotenone and tephrosin are flavonoids (Isoflavonoids) (Table 3), mostly isolated in the T. vogelii and been reported to exhibit poisonous effects on insects, fishes, and ectoparasites [15-18]. Therefore, the observed sedation signs could be attributable by the flavonoids (rotenoids) whose presence in the extracts is more likely.

On the other hand, the lethal dose could not be established because doses administered did not cause any death to the rats exposed to the doses. Certainly, control group and treated animals all survived. Apparently, these results give the impression that the lethal doses for both extract types must be higher than $5000 \mathrm{mg} / \mathrm{kg}$ body 
Table 1 Assessments during lethality $\left(\mathrm{LD}_{50}\right)$ test, recorded observations for $1-72 \mathrm{~h}$

\begin{tabular}{|c|c|c|c|c|c|c|c|c|c|}
\hline \multirow{2}{*}{$\begin{array}{l}\text { Parameters } \\
\text { for } \\
\text { Assessment }\end{array}$} & \multirow[b]{2}{*}{$\begin{array}{l}\text { TV-R, ME } \\
600\end{array}$} & \multicolumn{8}{|c|}{ Dose (mg/kg body weight) } \\
\hline & & $\begin{array}{l}\text { TV-R, ME } \\
1200\end{array}$ & $\begin{array}{l}\text { TV-R, ME } \\
2000\end{array}$ & $\begin{array}{l}\text { TV-R, ME } \\
5000\end{array}$ & $\begin{array}{l}\text { TV-L, ME } \\
600\end{array}$ & $\begin{array}{l}\text { TV-L, ME } \\
1200\end{array}$ & $\begin{array}{l}\text { TV-L, ME } \\
2000\end{array}$ & $\begin{array}{l}\text { TV-L, ME } \\
5000\end{array}$ & Control group \\
\hline Feeding & $\mathrm{N}$ & $\mathrm{N}$ & $\mathrm{N}$ & $\mathrm{N}$ & $N$ & $N$ & $N$ & $\mathrm{~N}$ & $\mathrm{~N}$ \\
\hline Fur condition & N & N & N & N & N & N & N & N & N \\
\hline Eye colour & N & N & N & N & $N$ & N & N & N & N \\
\hline Convulsion & N & N & N & N & $\mathrm{N}$ & $\mathrm{N}$ & N & $\mathrm{N}$ & $\mathrm{N}$ \\
\hline Locomotion & N & N & N & N & $N$ & N & N & N & N \\
\hline Sedation & $\mathrm{N}$ & $\mathrm{N}$ & N & $\mathrm{Ab}$ & $\mathrm{N}$ & N & N & $\mathrm{Ab}$ & $\mathrm{N}$ \\
\hline Survive/Death & S & S & S & $S$ & $\mathrm{~S}$ & S & $S$ & S & $S$ \\
\hline
\end{tabular}

Key: "Normal (N) or Abnormal (Ab)"; "Survive (S) or Death (D)"

weight, which is the highest reference dose [29, 33]. In this regard, extracts may be considered safe at the tested levels of $5000 \mathrm{mg} / \mathrm{kg}$ body weight and below [29, 30, 33]. Since the $\mathrm{LD}_{50}$ test of methanolic root and leaf extracts could not exhibit dreadful outcomes from all doses subjected, then it can be reasoned that the compounds in the extracts probably do not express any deleterious effects on the rats at the doses below $5000 \mathrm{mg} / \mathrm{kg}$ body weight.

Although the physical appearances of rats suggested that the extracts doses were not lethal, histopathological examinations were vital and employed to check any predicaments that could be occurring at a cellular level. To achieve this, a sub-acute toxicity evaluation experiment was conducted. The clinical signs in subjected animals following sub-acute toxicity assessments were immediately recorded after oral dose administration (Table 2). The signs were important indicators to explain the physical effects of doses on animals. Interestingly, even the sub-acute toxicity assessments could not exert any physical abnormality among set clinical signs. This means the subjected animals did not indicate any toxicity symptoms for doses below $2000 \mathrm{mg} / \mathrm{kg}$ body weight.

The histopathological examination of hepatic-renal tissues or cell architectures after repetitive dosage regime of $T$. vogelii in rats conducted to predict sub-acute toxicity effects for humans [44]. The treated rats' liver and kidney organs were macroscopically observed normal as compared to the control animal group. Consistently, the histopathological examination of the kidneys treated with both methanolic leaf and root extracts did not exhibit any histopathological degeneration of tissue or cells because there was no deleterious alteration of the cellular machinery as compared to the control (Fig. 1). Therefore, the tissues and cells exposed to the doses of leaf and root extracts of $T$. vogelii administered remained consistently unaffected across the experiments which would be interpreted that the doses caused no deleterious effects on the kidneys; and these results are congruent with other studies $[45,46]$. Similarly, the histopathological examination of the liver treated with methanolic leaf extracts doses of 600, 1200 and 2000 $\mathrm{mg} / \mathrm{kg}$ body weight of $T$. vogelii for all assessed animals

Table 2 Assessments during Sub-acute toxicity study, recorded observations from day 1-28

\begin{tabular}{|c|c|c|c|c|c|c|c|}
\hline \multirow{2}{*}{$\begin{array}{l}\text { Parameters for } \\
\text { Assessment }\end{array}$} & \multicolumn{7}{|c|}{ Dose $(\mathrm{mg} / \mathrm{kg})$} \\
\hline & $\begin{array}{l}\text { TV-R, ME } \\
600\end{array}$ & $\begin{array}{l}\text { TV-R, ME } \\
1200\end{array}$ & $\begin{array}{l}\text { TV-R, ME } \\
2000\end{array}$ & $\begin{array}{l}\text { TV-L, ME } \\
600\end{array}$ & $\begin{array}{l}\text { TV-L, ME } \\
1200\end{array}$ & $\begin{array}{l}\text { TV-L, ME } \\
2000\end{array}$ & Control group \\
\hline Feed intake & $\mathrm{N}$ & $\mathrm{N}$ & $\mathrm{N}$ & $N$ & $N$ & $N$ & $N$ \\
\hline Water intake & $\mathrm{N}$ & $\mathrm{N}$ & $N$ & $N$ & $N$ & $N$ & N \\
\hline Fur condition & N & $\mathrm{N}$ & $\mathrm{N}$ & N & $\mathrm{N}$ & $N$ & N \\
\hline Eye colour & $\mathrm{N}$ & $\mathrm{N}$ & $\mathrm{N}$ & $N$ & N & $\mathrm{N}$ & N \\
\hline Convulsion & N & $\mathrm{N}$ & $\mathrm{N}$ & $N$ & $N$ & $N$ & N \\
\hline Locomotion & $\mathrm{N}$ & $\mathrm{N}$ & $\mathrm{N}$ & $N$ & $\mathrm{~N}$ & $N$ & N \\
\hline Sedation & $\mathrm{N}$ & $\mathrm{N}$ & $\mathrm{N}$ & $N$ & $N$ & $\mathrm{~N}$ & N \\
\hline Aggressiveness & $\mathrm{N}$ & $\mathrm{N}$ & $\mathrm{N}$ & $N$ & $N$ & $N$ & N \\
\hline Behaviour & $\mathrm{N}$ & $\mathrm{N}$ & $\mathrm{N}$ & $N$ & N & $\mathrm{N}$ & N \\
\hline Survive or Death & $\mathrm{S}$ & $\mathrm{S}$ & $S$ & $\mathrm{~S}$ & S & $S$ & S \\
\hline
\end{tabular}

Key: "Normal (N) or Abnormal (Ab)"; “Survive (S) or Death (D)" 


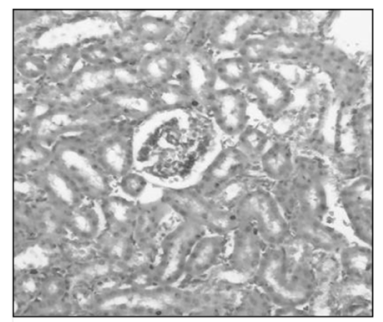

(A) Normal

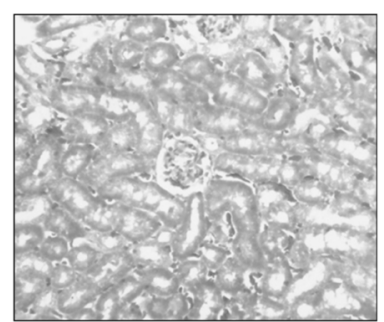

(B) Kidney vs TV-R, ME

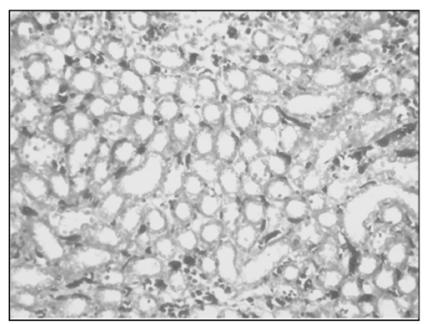

(C) Kidney vs TV-L, ME

Fig. 1 Histopathological examination of kidney section parts ( $H$ \& E stained under 10x magnification power) where the slide; (a) represent control (normal) (b) represent kidney tissues treated with TV-R, ME at doses of 600, 1200 and $2000 \mathrm{mg} / \mathrm{kg}$ (c) represent kidney tissues treated with TV-L, ME at doses of 600,1200 and $2000 \mathrm{mg} / \mathrm{kg}$ body weight

revealed that the tissues and cells were normal (Figs. $2 \mathrm{~b}$ $\& 3 \mathrm{~b})$, because were not different from the control group (Figs. 2a \& 3a). Thus, the leaf methanolic extracts doses did not cause harm to both subjected kidney and liver organs. Correspondingly, the methanolic root extracts doses of 600 and $1200 \mathrm{mg} / \mathrm{kg}$ body weight of T. vogelii revealed normal liver cells from the treated animals as compared to the control animal group (Figs. 2c \& 3c).

On the contrary, the dose of $2000 \mathrm{mg} / \mathrm{kg}$ body weight of methanolic root extract caused hepatic vacuolation (inflammations) and hepatic necrosis on day 14 (Fig. 2d). Regarding to literature we think saponins, terpenes and flavonoids might contribute toxicity of such hepatic inflammations and necrosis [47, 48]. Of course, this adverse phenomenon could be attributed to a large quantity (content) of the poisoning secondary metabolites contained in the $2000 \mathrm{mg} / \mathrm{kg}$ of methanolic root extracts. Hence suggesting that compoundcell interactions were magnified at the high dose administered for a prolonged time [49, 50]. Thus, histopathological findings from the liver signposted that administered lower doses $(600$ and $1200 \mathrm{mg} / \mathrm{kg}$ ) of methanolic root extracts of $T$. vogelii were not hepatotoxic as compared to $2000 \mathrm{mg} / \mathrm{kg}$ body weight which was inflammatory and necrotic to the liver after dose ingestion in 14 days. Interestingly, extending the duration without administration of the same dose to another 2 weeks (between 15 and 28 days), resulted in the disappearance of inflammations and necrosis in the hepatocytes. Therefore, there was a complete cellular recovery on the 28th day of the histopathological assays.

Typically, the cellular recovery suggested that the adverse effects of the bioactive compounds at $2000 \mathrm{mg} /$ $\mathrm{kg}$ body weight dose on the hepatocytes were temporary (Fig. 3c). This suggests further that the toxicity is influenced by high concentrations of the compound(s) whose toxicity fades as time increases [40,48]. Perhaps, the toxicity disappearance of the compound(s) may be due to the cell self-protection mechanism, which might be increasing over time. Despite the ability of the hepatocytes to recover after 2 weeks of the dose administration,

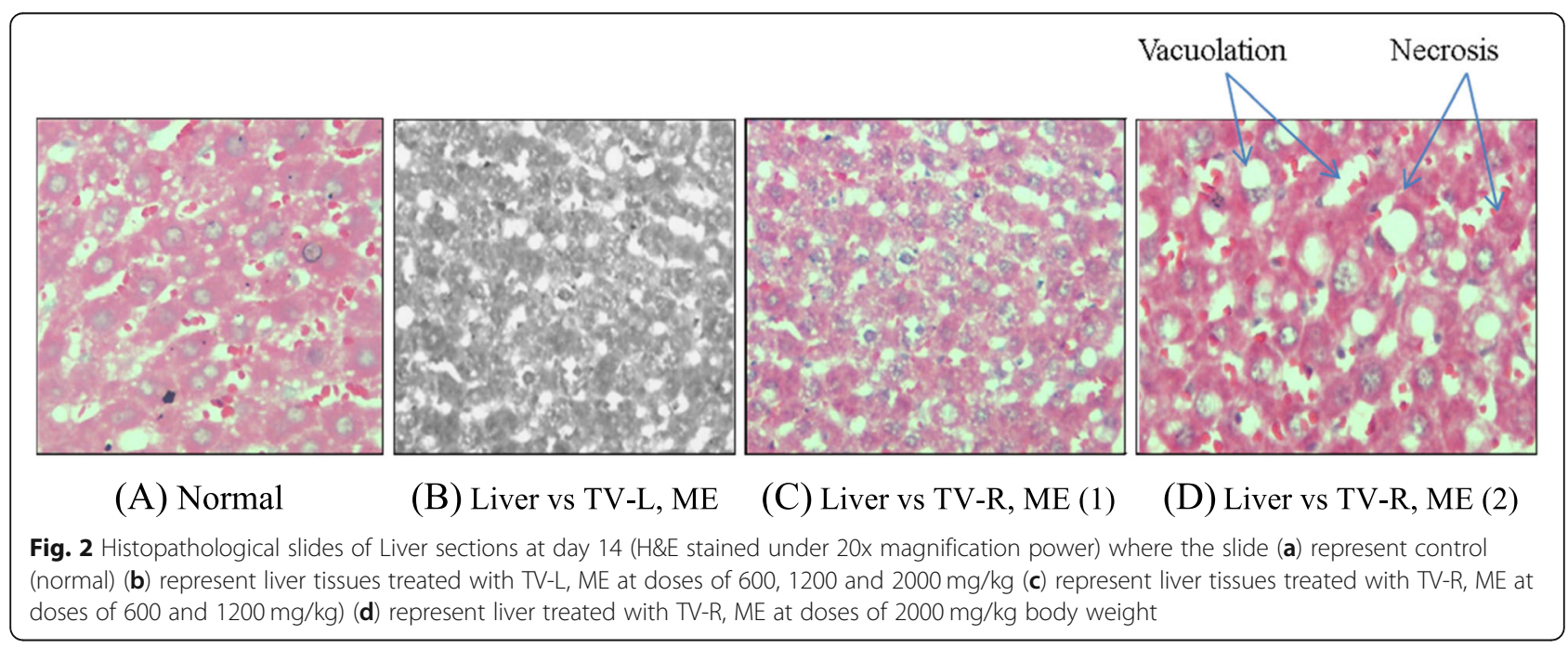




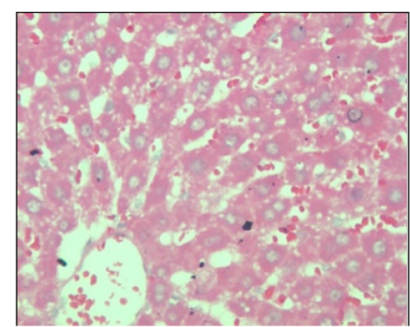

(A) Normal

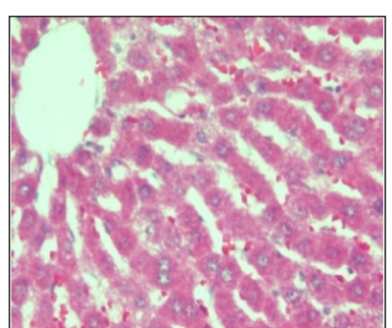

(B) Liver vs TV-L, ME

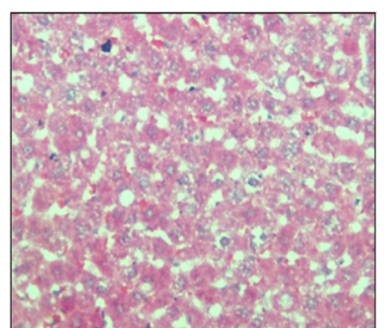

(C) Liver vs TV-R, ME

Fig. 3 Histopathological slides of liver section at day 28, (H\&E stained under 20x magnification power) where the slide (a) represent Liver tissues of control (b) Liver tissues treated with TV-L, ME of doses 600, 1200 and 2000 mg/kg (c) Liver tissues treated with TV-R, ME of doses 600, 1200 and $2000 \mathrm{mg} / \mathrm{kg}$ body weight

still, both observed inflammations and necrosis within 2 weeks should serve as a reminder that the $2000 \mathrm{mg} / \mathrm{kg}$ body weight dose and above may not be safe if administered for long term dose regime.

The toxicity of a substance is measured in terms of the extent to which that substance causes harm to cells or tissues. Toxins can be taken through ingestion or created by body physiological reactions. Regarding their roles, the liver and the kidney are vital organs, which are used as toxicity indices for evaluating the toxicity of pharmaceutical drugs and plant extracts [33]. For instance, since the liver and the kidney are detoxifying organs they are the first targets of toxicants administered that are easily and foremost affected [6]. Degenerations and alterations of tissue morphology such as hepatic vacuolation, necrosis, and hyperplasia are common evidence for the presence of the toxic substances in these detoxifying organs and they are responsible for liver and kidney damage or impairment $[6,47]$.

In this study, observed hepatic necrosis in the liver was indicative of cell deaths accompanied by the presence of Kupffer cells [49, 50]. Notably, several Kupffer cells (hepatic macrophages) emerged on the lining of the walls of the sinusoids of the liver treated with methanolic root extracts at the dose of $2000 \mathrm{mg} / \mathrm{kg}$ at day 14 .
Probably, these Kupffer cells were playing a protective role of hepatocytes through secretion of immuneregulatory mediators as well as orchestration of a cooperative system in the liver [50]. Apparently, the presence of numerous hepatic macrophages promotes the protection of the hepatocytes from toxic extracts and can be used as a toxicity alarm of a given dose; and it promotes the removal of senescent red blood cells and debris from portal blood flow [6]. The resultant hepatic vacuolation, characterized by cellular swellings or inflammations and nucleus shrinks, occurs as a cell selfprotection mechanism from poisons and toxicants [50].

Therefore, hepatic necrosis and vacuolation indicated that the hepatocytes were affected by chemical compound(s) contained in the root extracts at the dose of $2000 \mathrm{mg} / \mathrm{kg}$ of $T$. vogelii administered to rats for 14 days although time prolongation without the same dose to 28 days led to recovery and disappearance of hepatic necrosis and vacuolation. The quick tissue regeneration and disappearance of hepatic necrosis and vacuolation suggested that the toxicants either degraded or detoxified by the cell self-protection mechanism over time. Consequently, the dose did not demonstrate lethality. Although there was no lethality, the hepatic necrosis and vacuolation manifested by the dose of $2000 \mathrm{mg} / \mathrm{kg}$ of the

Table 3 Shows results of qualitative phytochemical test of leaf and root methanolic extracts

\begin{tabular}{|c|c|c|}
\hline \multirow{2}{*}{$\begin{array}{l}\text { Nature of } \\
\text { tested phytochemicals }\end{array}$} & \multicolumn{2}{|c|}{ Results of phytochemical test of extracts screened } \\
\hline & TV-R, ME & TV-L, ME \\
\hline Tannins & + & + \\
\hline Terpenes & + & + \\
\hline Saponins & + & + \\
\hline Flavonoids & + & + \\
\hline Alkaloids & - & - \\
\hline Glycosides & + & + \\
\hline Steroids & + & + \\
\hline Anthraquinones & - & - \\
\hline
\end{tabular}

Key: $(+)=$ present; $(-)=$ absent 
root methanolic extracts warn that this dose or above may not be safe.

\section{Conclusion}

Toxicity evaluation of herbal medicines is paramount in order to provide safety assurance of their subsequent used herbal products. The magnitude of toxicity of the drug(s) is determined through lethality and degeneration on the vital organs particularly the liver and the kidney tissues or cells. The in vivo toxicity evaluation of methanolic root and leaf extracts of $T$. vogelii revealed no mortality cases even at the highest dose of $5000 \mathrm{mg} / \mathrm{kg}$ body weight of the albino rats suggesting that the extracts were not deadly. Histopathological examination of kidney and liver did not show alterations in tissue morphology for both root and leaf extracts doses of 600, and $1200 \mathrm{mg} / \mathrm{kg}$ body weight. Histopathological evaluation revealed that leaf extracts were safe in all administered dosage while root extracts exhibited toxicity in the liver at the dosage of $2000 \mathrm{mg} / \mathrm{kg}$ body weight. Thus, toxicity evaluation of both leaf and root methanolic extracts of T. vogelii advocates that the dose of less than $2000 \mathrm{mg} /$ $\mathrm{kg}$ body weight may be ideal for the formulation of antimicrobial products. Moreover, these results contributed the toxicity profile of $T$. vogelii that may be useful to practitioners using it as herbal medicine. Importantly, the identification of chemical compounds from the root extracts for which a concentration higher than $2000 \mathrm{mg} /$ $\mathrm{kg}$ causes hepatic necrosis and vacuolation and how they cause them, need to be investigated in the future study.

\section{Abbreviations}

KIDH: Kibong'oto Infectious Diseases Hospital; NM-AIST: Nelson Mandela African Institution of Science and Technology; CEDHA: Centre for Educational Development in Health, Arusha; HREC: Health Research Ethics Committee; KNCHREC: "Kibong'oto Infectious Diseases Hospital - Nelson Mandela African Institution of Science and Technology - Centre for Educational Development in Health, Arusha, Health Research Ethics Committee"

\section{Acknowledgements}

We thank the Mkwawa University College of Education for sponsorship. We extend our appreciation to Dr. E.B. Mngumi and Mr. J. Mbilu for the laboratory technical support as well as Mr. E. John for plant identification.

\section{Declaration}

We the authors declare that this manuscript is original, has not been published before and is not currently being considered for publication elsewhere. We confirm that the manuscript has been read and approved by all authors for publication.

\section{Authors' contributions}

This work was furnished out in collaboration between both authors. SHM designed the study, wrote the protocol and analysed data under supervision of JAM and MC. Two authors, JAM and MC played same role of guiding and coaching SHM to carry out experiments and participated in writing the manuscript. The authors read and approved the final manuscript.

\section{Funding}

All funds to furnish this study were provided by Mkwawa University College of Education.
Availability of data and materials

The data used in this study for analysis are available from the corresponding author on reasonable request.

\section{Ethics approval and consent to participate}

Written ethical clearance permit was provided by Tanzania National Institute for Medical Research (NIMR) through Northern zone Health Research Ethics Committee, permit registration is KNCHREC Ref No. 00022.

\section{Consent for publication}

Not applicable.

\section{Competing interests}

The Authors declare no conflicts of interest.

Received: 26 January 2020 Accepted: 3 November 2020

Published online: 10 November 2020

References

1. Ha AW, Kang HJ, Kim SL, Kim MH, Kim WK. Acute and subacute toxicity evaluation of corn silk extract. Prev Nutr Food Sci. 2018:23:70-6.

2. Gurib-Fakim A. Medicinal plants: traditions of yesterday and drugs of tomorrow. Mol Asp Med. 2006:27:1-93.

3. Dewick PM. Medicinal natural product: a biosynthetic approach. 3rd ed. United Kingdom: Wiley; 2009

4. Tom ENL, Nyunaï N, Djaouro KG, Mba Medou F, Nankia FD, Dimo T. Acute and subacute toxicity evaluation of the stem bark aqueous extract of Harungana madagascariensis in rodents. J Adv Pharm Sci Technol. 2018; $1: 1-12$.

5. Nath P, Yadav AK. Acute and sub-acute oral toxicity assessment of the methanolic extract from leaves of Hibiscus rosa-sinensis L. in mice. J Intercult Ethnopharmacol. 2015:4:70-3.

6. Bello I, Bakkouri AS, Tabana YM, Al-hindi B, Al-Mansoub MA, Mahmud R, et al. Acute and sub-acute toxicity evaluation of the methanolic extract of Alstonia scholaris stem bark. Med Sci. 2016;4:1-14.

7. Toghueo RMK. Bioprospecting endophytic fungi from Fusarium genus as sources of bioactive metabolites metabolites. Mycology. 2019;91:1-21.

8. Jatsa HB, Fassi J, Kenfack MMC, Feussom NG, Kameni M, Simo NND, et al. Acute and sub-chronic oral toxicity studies of the leaves aqueous extract of Clerodendrum umbellatum Poir. on mice. Am J Physiol Biochem Pharmacol. 2018:7:75-85.

9. Kilonzo M, Ndakidemi PA, Chacha M. In vitro antifungal and cytotoxicity activities of selected Tanzanian medicinal plants. Trop J Pharm Res. 2016;15: 2121-30.

10. Orwa C, Mutua A, Kindt R, Jamnadass R, Anthony S. Tephrosia vogelii Hook.f. Fabaceae - Papilionoideae. Agroforestry Database. 2009; http://apps. worldagroforestry.org/treedb/AFTPDFS/Tephrosia_vogelii.PDF. Accessed 10 Oct 2020.

11. Makoshi M, Arowolo ROA. Therapeutic effects of Tephrosia vogelii ointment in the treatment of bovine dermatophilosis. J Vet Med Anim Health. 2011;3: 51-5.

12. Gadzirayi CT, Mutandwa E, Mwale M, Chindundu T. Utilization of Tephrosia vogelii in controlling ticks in dairy cows by small-scale commercial farmers in Zimbabwe. African J Biotechnol. 2009:8:4134-6.

13. Li W, Huang C, Wang K, Fu J, Cheng D, Zhang Z. Laboratory evaluation of aqueous leaf extract of Tephrosia vogelii against larvae of Aedes albopictus (Diptera: Culicidae) and non-target aquatic organisms. Acta Trop. 2015:146:36-41.

14. Russell DA, Freudenreich JJ, Ciardiello JJ, Sore HF, Spring DR. Stereocontrolled semi-syntheses of deguelin and tephrosin. Org Biomol Chem. 2017;15:1593-6.

15. Dzenda T, Ayo JA, Adelaiye AB, Adaudi AO. Ethno-medical and veterinary uses of Tephrosia vogelii hook. F.: a review. Niger Vet J. 2008;28:24-39.

16. Inalegwu B, Sodipo OA. Antimicrobial and foam forming activities of extracts and purified saponins of leaves of Tephrosia vogelii. Eur J Exp Biol. 2015;5:49-53.

17. Mwaura L, Stevenson PC, Ofori DA, Anjarwalla $P$, Jamnadass $R$, Smith $P$. Pesticidal Plant Leaflet: Tephrosia vogelii Hook.f: World Agroforestry Centre; 2013. http://apps.worldagroforestry.org/downloads/Publications/PDFS/ LE13137.pdf. Accessed 10 Oct 2020. 
18. Stevenson PC, Belmain SR. Tephrosia vogelii: a pesticide of the future for African farming. Boletín SEEA. 2017;2:19-22.

19. Kalume MK, Losson B, Angenot L, Tits M, Wauters JN, Frédérich M, et al. Rotenoid content and in vitro acaricidal activity of Tephrosia vogelii leaf extract on the tick Rhipicephalus appendiculatus. Vet Parasitol. 2012;190: 204-9.

20. Mlozi SH, Mmongoyo JA, Chacha M. Antimicrobial activities of Tephrosia vogelii against selected pathogenic fungi and bacteria strains. Mycology. 2020;11:49-55.

21. Kujur RS, Singh V, Ram M, Yadava HN, Singh KK, Kumari S, et al. Antidiabetic activity and phytochemical screening of crude extract of Stevia rebaudiana in alloxan-induced diabetic rats. Pharm Res. 2010;2:258-63.

22. Dubey M. Sushma. Phytochemical status of some selected medicinal plants (Eclipta alba, Cathranthus roseus and Swertia chirata). Asian J Plant Sci Res. 2014;4:28-34.

23. Tiwari P. Bimlesh Kumar, Kaur M, Kaur G, Kaur H. phytochemical screening and extraction: a review. Int Pharm Sci. 2011;1:98-106.

24. Onwukaeme DN, Ikuegbrweha TB, Asonye CC. Evaluation of phytochemical constituents, antibacterial activities and effect of exudate of Pycanthus angolensis (Myristicaceae) on corneal ulcers in rabbits. Trop J Pharm Res. 2007;6:725-30

25. OCDE. OECD guideline for testing of chemicals: OECD 423; 2001. p. 1-14.

26. OECD. OECD guideline for testing of chemicals: OECD 407; 2008. p. 1-13.

27. Chinedu E, Arome D, Ameh FS. A new method for determining acute toxicity in animal models. Toxicol Int. 2013;20:224-6.

28. Yadav MK, Singh SK, Singh M, Mishra SS, Singh AK. In vivo toxicity study of ethanolic extracts of Evolvulus alsinoides \& Centella asiatica in Swiss albino mice. Open Access Maced J Med Sci. 2019;7:1071-6.

29. Nanthini K, Kanakavalli K, Kaliyamurthy V. Acute and sub acute toxicity study on siddha drug Mandoora chooranam. Int J Pharm Biol Arch. 2014;5:86-91.

30. Porwal M, Khan NA, Maheshwari KK. Evaluation of acute and subacute ora toxicity induced by ethanolic extract of Marsdenia tenacissima leaves in experimental rats. Sci Pharm. 2017;85:1-11.

31. Shorinwa OA, Monsi B. Toxicological implications of the fruit of Harungana madagascariensis on Wistar rats. Clin Phytoscience. 2020;6:1-9.

32. Kifayatullah M, Mustafa MS, Sengupta P, Sarker MR, Das A, Das SK. Evaluation of the acute and sub-acute toxicity of the ethanolic extract of Pericampylus glaucus (lam.) Merr. In BALB/c mice. J Acute Dis. 2015; 4:309-15.

33. Olaniyan JM, Muhammad HL, Makun HA, Busari MB, Abdullah AS. Acute and sub-acute toxicity studies of aqueous and methanol extracts of Nelsonia campestris in rats. J Acute Dis. 2016:5:62-70.

34. Animal Welfare Act: Enacted by Parliamentary of the United Republic of Tanzania. 2008.

35. Prescott MJ, Lidster K. Improving quality of science through better animal welfare: the NC3Rs strategy. Altern Lab Anim. 2017:46:152-6.

36. Balls M, Goldberg AM, Fentem JH, Broadhead CL, Burch RL, Balls M, et al. The three Rs: the way forward. Altern Lab Anim. 1995;23:838-66.

37. Zhao YL, Su M, Shang JH, Wang X, Njateng GSS, Bao GL, et al. Acute and chronic toxicity of indole alkaloids from leaves of Alstonia scholaris (L.) R. Br. In mice and rats. Nat Prod Bioprospect. 2020;10:77-88.

38. Upadhyay P, Shukla R, Tiwari KN, Dubey GP, Mishra SK. Toxicity assessment of the alcoholic leaves extract of Reinwardtia indica. Braz J Pharm Sci. 2019; 55:1-8.

39. Ghosh D, Mondal S, Ramakrishna K. Acute and sub-acute (30-day) toxicity studies of Aegialitis rotundifolia Roxb., leaves extract in Wistar rats: safety assessment of a rare mangrove traditionally utilized as pain antidote. Clin Phytoscience. 2019;5:1-16.

40. Amy MH, DeWitt BA, Lukes AL. Potential interactions between alternative therapies and warfarin. Am J Heal Pharm. 2000;57:1221-7.

41. Ekor $\mathrm{M}$. The growing use of herbal medicines : issues relating to adverse reactions and challenges in monitoring safety. Front Pharmacol. 2014;4: $1-10$.

42. Maregesi SM, Mwakigonja AR, Urio P. Toxicity evaluation of Abrus precatorius seeds collected from Bunda District, Tanzania. Sch Acad J Pharm. 2016;5:399-405

43. Emerole G, Thabrew MI, Anosa V, Okorie DA. Structure-activity relationship in the toxicity os some naturally occuring Coumarins-chalepin, imperatorin and oxypeucedanine. Toxicology. 1981;20:71-80.
44. Ibrahim B, M'batchi M, Mounzeo H, Bourobou HPB. Effect of Tephrosia vogelii and Justicia extensa on Tilapia nilotica in vivo. J Ethnopharmacol. 2000;69:99-104

45. Ling N. Rotenone - a review of its toxicity and use for fisheries management. Science Conservation 211. Department of Conservation; 2003.

46. Caboni P, Sherer TB, Zhang N, Taylor G, Na HM, Greenamyre JT, et al. Rotenone, deguelin, their metabolites, and the rat model of Parkinson's disease. Chem Res Toxicol. 2004;17:1540-8.

47. Olson H, Betton G, Robinson D, Thomas K, Monro A, Kolaja G, et al. Concordance of the toxicity of pharmaceuticals in humans and in animals. Regul Toxicol Pharmacol. 2000;32:56-67.

48. Kilonzo M, Ndakidemi PA, Chacha M. Acute oral toxicity study of Mystroxylon aethiopicum root bark aqueous extract in albino mice. J Med Plants Res. 2016;10:656-61.

49. Patel S, Nag MK, Daharwal SJ, Singh MR, Singh D. Plant toxins: an overview. Res J Pharmacol Pharmacodyn. 2013;5:283-8.

50. Henrich CJ, Beutler JA. Matching the power of high throughput screening to the chemical diversity of natural products. Nat Prod Rep. 2013;30:128498.

\section{Publisher's Note}

Springer Nature remains neutral with regard to jurisdictional claims in published maps and institutional affiliations.

\section{Submit your manuscript to a SpringerOpen ${ }^{\circ}$ journal and benefit from:}

- Convenient online submission

- Rigorous peer review

- Open access: articles freely available online

- High visibility within the field

- Retaining the copyright to your article

Submit your next manuscript at $>$ springeropen.com 